\title{
A wonderful analogy between Augustine's definition of moral-value- functional sense of response-action and Philo's definition of truth-functional sense of implication in logic
}

\section{Una analogía sorprendente entre la definición agustiniana de significado moral-funcional de la acción de respuesta y la definición filónica del significado verdadero-funcional de la implicación en la lógica}

\author{
Vladimir O. Lobovikov \\ Institute of Philosophy and Law of the Academy of Sciences, Russia \\ vlobovikov@mail.ru \\ (D) http://orcid.org/0000-0001-8760-0452
}

Recepción: 30 de mayo de 2019

Aprobación: 04 de diciembre de 2019

\begin{abstract}
The paper is devoted to interdisciplinary research at the intersection of symbolic logic, mathematical ethics, and philosophical theology. By comparing definitions of relevant functions, a surprising analogy is discovered between the well-known Philo's precise definition of implication in logic (classical one) and Augustine's precise definition of God's morally good reaction to human actions. The moral-value-table-representation of Augustinian doctrine is compared with moral-value-table-representations of Pelagius' and Leo Tolstoy's views of adequate moral-response-actions.

KEYWORDS: philo definition of truth functional sense of implication in logic, Augustinian definition of moral value functional sense of response action, Leo Tolstoy, Pelagius, two valued algebra of formal axiology.

\section{Resumen}

El artículo trata de investigaciones interdisciplinarias en la intersección de la lógica simbólica, la ética matemática y la teología filosófica. Al comparar definiciones de funciones relevantes, se descubre una analogía sorprendente entre la conocida definición precisa (dada por Filón) de implicación clásica en la lógica y la definición precisa agustiniana de la reacción moralmente perfecta de Dios a las acciones humanas. La representación (modelación) de la doctrina agustiniana, mediante una tabla de valores morales, es comparada con modelos (representados por tablas de valores morales) de las opiniones de Pelagio y Leo Tolstoi sobre la adecuación moral de acciones de respuesta. Palabras Clave: la definición filónica del significado verdadero funcional de la implicación en la lógica, definición agustiniana de significado moral funcional de la acción de respuesta, Leo Tolstoi, Pelagio, álgebra de axiología formal de dos valores.
\end{abstract}

\section{INTRODUCTION}

The present article submits further developing the significantly new scientific results presented at the International Conference (Lobovikov, 2015a) and at the World Congress (Lobovikov, 2015b). At the very beginning of this interdisciplinary paper unexpectedly combining philosophical theology, two-valued algebra of formal ethics (formal axiology), and symbolic logic, it is relevant to place the following very important citation from "On Grace and Free Choice" by Augustine of Hippo:

God will fully render evil for evil, since He is just; good for evil, since He is good; good for good, since He is good and just. However, He will not render evil for good, since He is not unjust. Therefore, He will render evil for evil as the penalty for injustice; He will render good for evil as grace for injustice; He will render good for good as 'grace for grace' [Jn. 1:16]. Return to this treatise regularly. If you understand it, give thanks to God. Where you do not understand it, pray that you may understand it, for the Lord will give you understanding (Augustine, 2010, pp. 183-184). 
The above-given citation from "On Grace and Free Choice" is the only excerpt of Augustine I analyze in this article. I would like to draw the special attention of the reader to it, as this is my main explicandum. This paper deals with an explication and tabular modeling of the cited text.

Today there is a great quantity of publications about Doctor of Grace's life and legacy, (Bonner, 1963; 1987; Couenhoven, 2007; Farrelly, 1964; Fitzgerald, 1999; Lancel, 2002; Rist, 1994; Tillich, 1968; Watson, 1959; Wetzel, 1992; Yates, 2006). By virtue of many talented researchers nowadays the historical attitude to investigating Augustine's life and legacy is well-developed and elaborated in detail. The present article is devoted to investigating not the concrete history but an abstract theory relevant to the case. Moreover, the meant abstract theory is to be equipped with mathematical apparatus used in symbolic logic, namely, with the tabular method.

It would be very good if readers have the relevant knowledge of the tabular method used in basic symbolic logic [otherwise look into (Kleene, 1967; Mendelson, 1997)] and also have the relevant knowledge of Christian theology doctrine (Augustine, 1963; 1994; 2010; Pseudo-Dionysius, 1980; Aquinas, 1975; 1994a; 1994b) at their disposal. Also, it would be very good if readers have knowledge of Pelagius' and Leo Tolstoy's non-classical Christian theology conceptions concerning the relevant theme (Pohle, 1911; Tolstoy, 1942; 1970; 1990; 2005; 2009) which conceptions were factually labeled as heresies by the Church courts. The courts used the word "heresy" in its negative meaning as an expression of hatred. On the contrary in the present academic work the word "heresy" is used in a neutral meaning: it stands for the historical fact that Pelagius' and Tolstoy's non-classical Christian theology views were evaluated as false and heretic ones.

\section{Tabular models of the heresies of PelagiUs aND tOlstoy aND OF THEIR INTERRElations WITH AUGUSTINE'S DOCTRINE OF GRACE AND FREE CHOICE}

Count Tolstoy insisted that according to adequately understood Christianity, it is bad to commit a bad action in response to committing a bad action, consequently, all activities of coercive powers of state (courts, police, prisons, army, etc.) are morally bad and must be terminated (Tolstoy, 1942; 1970; 1990; 2005; 2009). It is easy to predict state reaction to such moral-religious claim of the count.

Pelagius insisted that it is good to commit a bad action in response to committing a bad action (as this is just), but it is bad to commit a bad action in response to a good action, consequently, as God does not realize morally bad actions, man can determine Him by performing exclusively good deeds. Good man does not need God's Grace. Human salvation depends upon human free moral choice completely (Pohle, 1911). It is easy to notice that Pelagius' and Leo Tolstoy's non-classical Christian theology conceptions are logically incompatible. Moreover, both conceptions are logically incompatible with classical Christian theology doctrine developed by St. Augustine.

Augustine Aurelius of Hippo (called "Doctor of Grace") insisted that it is good to perform a bad action in response to committing a bad action (as this is just), and it is also good to accomplish a good action in response to bad one, as it is grace. God's Grace is necessary for human salvation as (from the moral-rigor point of view) man is morally bad one as his conduct as a whole is morally bad. Man is weak and hence not able to determine God (who is free and hence not determined). The only chance of the "fallen man" salvation is based upon God's Grace. Therefore, Augustine of Hippo (called also "Augustine the Blessed") insisted that it is good to accomplish a good action in response to bad one. This statement of moral goodness of grace-reaction unites Augustine with Tolstoy but separates from Pelagius. The here-described original position of Augustine is very well represented by himself in the above-cited aspect of his "On Grace and Free Choice". I advise the reader to look into the above citation again attentively as it is very important for this article.

Now everything is prepared for understanding my claim that the moral-value-functional aspect of the moral-theology-controversies among the three prominent thinkers can be modeled by the following table 1 . 
TABLE 1

Definitions of moral-value-functional-sense of different options of moral operation Cxy ("realizing $y$ in response to realizing $x ")$

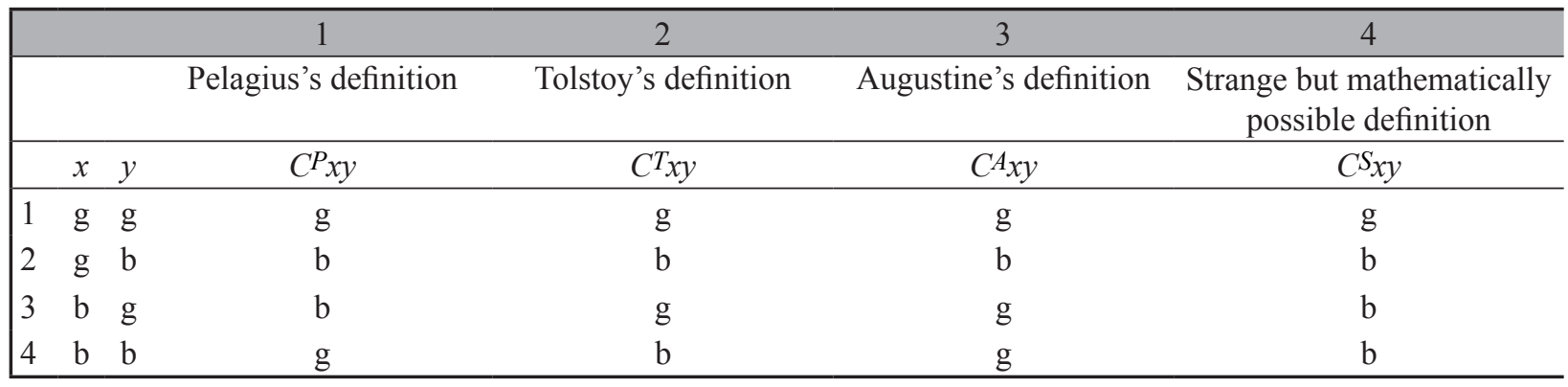

Source: Own elaboration

In table 1 the moral variables $x$ and $y$ range over the set of moral actions, which, by definition, are either morally good or bad ones. The moral-value arguments and moral-value functions take their values from the $\operatorname{set}\{g($ good), $b$ (bad)\}, elements of which are called moral values (of moral actions). [1] The symbol $C x y$ in the above table stands for the moral operation "realizing $y$ in response to realizing $x$ ". In $C P x y$ the upper literal index $P$ informs that this is Pelagius's option of defining moral-value-function $C x y$. In $C T x y$ the upper literal index $T$ informs that this is Tolstoy's option of defining moral-value-function $C x y$. In $C A x y$ the upper literal index $A$ informs that this is Augustine's option of defining moral-value-function Cxy.

The upper rows 1 and 2 of the table 1 are not problematic: they are quite natural and produce no debates; all people agree with them; moral intuition does not protest against the rows 1 and 2 . Therefore they are excluded from the subject-matter of discussion in this paper. The present article is precisely aimed at discussing and investigating lower rows 3 and 4 of the table 1.

Those who are somehow acquainted with elementary symbolic logic easily notice that the column 3 of the table 1 under consideration is surprisingly similar to the below-presented well-known tabular definition of truth-functional sense of "(material) implication" in classical algebra of propositional logic. (In the below table 2: symbol " $\supset$ " stands for the implication; letters "A" and "B" stand for propositions; letters " $\mathrm{t}$ " and " $\mathrm{f}$ " - for the truth-values "true" and "false", respectively.) The source of the table 2 - (Kleene 1967; Mendelson 1997).

TABLE 2

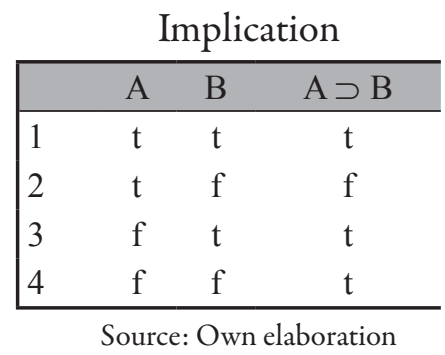

It is noteworthy that in history of logic the upper rows 1 and 2 of the table 2 produced no significant debates analogously. These rows were recognized as quite natural; all people accepted them; logic intuition did not protest against the rows 1 and 2. But the lower rows 3 and 4 of the table 2 produced hard controversies. Since Antiquity (Bobzien, 2015; Mates, 1961; Epstein, 2001) the two lower rows were considered as paradoxes of the conditional (material implication) in logic. In the literature on history of logic the truth-functional definition of implication above-represented by the table 2 has been associated with Philo the Logician of Megara. In "Principia Mathematica" A. N. Whitehead and B. Russel had formalized Philonian implication called "material one" by C.I. 
Lewis. Since Chrysippus epoch to Lewis times Philonian implication had been sharply criticized as inadequate (not sound) formalization of the ordinary language "if... then...".

In XX century attempts to overcome these paradoxes resulted in constructing non-classical logic systems, especially, ones of relevant-logic (Anderson \& Belnap, 1975; Mares, 2004) and paraconsistent-logic (Costa, 1974; Costa et al., 2007; Béziau, 1999). The direct attempt to solve the paradoxes of material (Philonian) implication is the relevant logic. However, the paraconsistent logic is indirectly connected with solving these paradoxes as accepting paraconsistent logic implies rejecting the material (Philonian) implication as a meaning of the word "entails".

In the given paper it is worth emphasizing the existence of a significant similarity (analogy) between formal logic and formal ethics which similarity is exemplified by comparing "implication" in formal-logic with "reaction (response-action)" in formal-ethics. According to the hexagon-of-opposition submitted in (Béziau, 2015) analogy implies both similarity and difference. As the difference between ethics and logic is obvious, the fact of similarity between them gives the right to affirm the analogy between the two. I believe that this similarity (analogy) is heuristically important. From the viewpoint of this analogy, it is quite natural that the above tabular definition 1 of the moral analogue of material implication is paradoxical (see the bottom rows 3, 4). Its paradoxical-ness is quite natural because there is a significant similarity between material implication and the moral analogue of it. As there is the analogy, it is verisimilar to conclude (by analogy) that as material implication is paradoxical, it is natural to expect that the moral analogue of it is paradoxical as well. This is a justification by analogy. Another option of showing obvious paradoxical-ness of the moral analogue of material implication is logical analysis of conjunction of Pelagius', Tolstoy's and Augustine's relevant statements. Obviously, the conjunction makes up a paradox in moral theology.

The above description of three different moral theology conceptions < Tolstoy; Pelagius; Augustine of Hippo> is performed at the level of natural language. Moreover, the description and comparison of the three is done within moral content analysis. However, there is a possibility to depart from content ethics to formal one. It was possible to find expressions "formal ethics" and "formal axiology" in Edmund Husserl's lectures on ethics but no artificial symbolic language was used, and no system of formal ethics was constructed by him (Husserl, 1988). He did not make an attempt to create an algebraic system offormal ethics in spite of the fact that he had noticed a significant analogy between formal logic and formal ethics (Husserl, 1988). When at the very beginning of 70-ies of the 20th century I constructed a two-valued algebraic system offormal ethics (by analogy with the two-valued algebraic system of formal logic) and started developing it systematically, I had lacked knowledge of Husserl's ideas of formal ethics.

My view of formal ethics as mathematized system is the following. By definition, the two-valued algebraic system of formal ethics (of moral rigor) is the triple $\langle A, F,=+=>$. In this triple A stands for the set of moral acts and agents (individual or collective ones - it does not matter). By definition, moral acts (=actions) are such and only such operations, which are either good, or bad ones (in the moral meaning of the words "good" and "bad") in relation to a moral evaluator $\Sigma$. By definition, moral agents (=persons) are such and only such agents (persons), which are either good, or bad ones in relation to the moral evaluator $\Sigma$. The symbol $\Sigma$ stands for that person (individual or collective one - it does not matter), in relation to which all evaluations are generated. In the moral-evaluation-relativity theory, $\Sigma$ is a variable: changing values of the variable $\Sigma$ can result in changing moral evaluations of concrete acts and agents. However, if a value of the variable $\Sigma$ is fixed, then moral evaluations of concrete acts and agents are definite.

In the above-mentioned triple, $F$ stands for the set of algebraic operations defined on the set $A$ of moral acts and moral agents, which operations are moral-value-functions (or moral-evaluation-ones). Moral-value-arguments of these functions take their values from the set $\{\mathrm{g}$ (good), $b(\mathrm{bad})\}$. The functions take their values from the same set. The symbols: " $x$ " and " $y$ " stand for moral-forms of acts (or moral-act-forms). Elementary moral-act-forms deprived of their contents are independent moral-evaluation-variables. Compound moral-act-forms deprived of their contents are moral-evaluation-functions determined by these variables. 
Speaking of moral-value-functions in this article I mean the following mappings (in the proper mathematical meaning of the word "mapping"): $\{g, b\} \rightarrow\{g, b\}$, if one speaks of the moral-value-functions determined by one moral-value-argument; $\{g, b\} \times\{g, b\} \rightarrow\{g, b\}$, where " $\times$ " stands for the Cartesian multiplication of sets, if one speaks of the moral-value-functions determined by two moral-value arguments; $\{g, b\} \mathrm{N} \rightarrow\{g, b\}$, if one speaks of the moral-value-functions determined by $\mathrm{N}$ moral-value-arguments, where $\mathrm{N}$ is a finite positive integer.

The symbol $=+=$ (in the above-mentioned triple) stands for the formal-ethical (formal-axiological) equivalence-relation, which is defined precisely in the below section 3 of this paper.

According to my conception of formal-axiological semantics of natural language, words, small word-combinations, and even long expressions stand for some moral-value-functions or for some complicated compositions of the functions (Lobovikov, 2009b; 2015d; 2015e).

\section{UNITY OF PHILOSOPHICAL THEOLOGY, LOGIC, AND ETHICS: TWO-VALUED ALGEBRAIC SYSTEM OF FORMAL ETHICS AS A GENERALIZATION OF THE TWO-VALUED ALGEBRAIC SYSTEM OF FORMAL LOGIC}

According to Christian religious tradition, God is One, but He has many somewhat different names, for instance, "Being", "Reason", "Nature”, "Law", "Power", "Beauty", “Truth”, "Good” [See (Pseudo-Dionysius, 1980; Augustine, 1963; 1994; 2010; Aquinas, 1975; 1994a; 1994b)]. However, despite the evident empirical difference of descriptive-indicative meanings of the mentioned words in the world of facts, their axiological meanings in the world of necessarily universal immutable values are identical. As "Truth" and "Good" are names of God, and He is One [See (Pseudo-Dionysius, 1980; Augustine, 1963; 1994; 2010; Aquinas, 1975; 1994a; 1994b)], there must be a fundamental axiological unity between logic dealing with truth and ethics dealing with good. In some sense, logic is an important part of theology as logic instructs humans how to think not leaving truth (of premises) for lie (of conclusions), i. e. how to think not leaving God for His enemy. The same can be said about the natural law and morals. They instruct living creatures how to behave not leaving good (actions) for evil, i. e. how to behave not leaving God for His enemy. In the empirical world facts (contingent truths) and contingent values are logically independent (Hume, 1977; Moore, 2004) but in the world of proper (necessary) being and proper (necessarily positive) value, logic and ethics make up a union (Aquinas, 1975; 1994a; Leibniz, 1971; Lobovikov, 2016; 2017). Moreover, even in the empirical world logic and ethics are significantly connected by the analogy [recognized, for example, by (Husserl, 1988) between logic structures of thinking and corresponding moral structures of acting.

According to famous Polish logician Jan Eukasiewicz; "Logic is morality of thought and speech" (Woleński, 2019). Let us consider possible consequences of accepting this statement, at least, as a hypothesis. Ethics deals with morality of any human activity (speaking-and-thinking is a particular case of acting). Consequently, moral-form-of-activity (deprived of its specific contents) is a generalization of logic-form of thought-and-speech (deprived of its specific contents). Consequently, formal ethics is a generalization of formal logic (Lobovikov, 1988; 1990; 2007; 2009a; 2009b; 2016). Hence there is such a subsystem of system of formal ethics, which completely coincides with the classical two-valued system of formal logic. This basic subsystem of formal ethics is nothing but two-valued system of formal ethics of moral rigor of speaking-and-thinking. The two-valued formal ethics of moral rigor does exist although, evidently, it is neither realistic nor humanistic one. However here it is important to recognize that the mentioned two-valued formal ethics of moral rigor is a much more universal doctrine than the classical logic. Let us consider the propositional classical logic as an example. Propositions are particular cases of moral actions. [2] Truth-values (true and false) of propositions are particular cases of moral values (good and bad) of actions, respectively. Hence the classical two-valued algebraic system of formal logic is a particular case of two-valued algebraic system of formal ethics (Lobovikov, 2009a; 2009b; 2016). Details (definitions, explanations, exemplifications, etc.) concerning this algebraic system of formal ethics can be found in (Lobovikov, 1984; 1988; 1990; 1998; 1999; 2007; 2014a; 2014b; 2016). However, it is indispensable to present some of these basic definitions here for studying consequences of the hypothesis in question. 
Definition 1 (of formal-ethical-equivalence-relation): in two-valued algebraic system of formal ethics, moral-evaluation-functions $\Omega$ and $\Psi$ are formally-ethically equivalent (this is represented by the symbol " $\Psi=+=\Omega$ "), if and only if they acquire identical moral values (from the set $\{\mathrm{g}(\operatorname{good}), b(\mathrm{bad})\})$ under any possible combination of moral values of their moral-evaluation-variables. The logic interconnection between the relations "formal-ethical-equivalence" and "formal-logical-equivalence" is represented graphically in (Lobovikov, 2015c; 2016).

Definition 2: (of formal-ethical-law): in two-valued algebra of formal ethics, a moral-evaluation-function $\Omega$ is called formally-ethically (or invariantly) good one (or a law of algebra of formal ethics), if and only if it acquires the moral value $g($ good $)$ under any possible combination of moral values of its variables. In other words, $\Omega$ is a formal-ethical-law in algebra of formal ethics, if and only if $\Omega=+=g$, i. e. iff $\Omega$ is the positive constant-moral-valuation-function. A graphic model of logic interconnection between the notions "formal-ethical-law" and "formal-logical-law" is submitted in (Lobovikov, 2015c; 2016).

Definition 3 (of formal-ethical contradiction): in two-valued algebra of formal ethics, a moral-evaluation-function is called formally-ethically (or invariantly) bad one (or a formal-ethical contradiction), if and only if it acquires the moral value $b(\mathrm{bad})$ under any possible combination of moral values of its variables. In other words, $\Omega$ is a formal-ethical contradiction in algebra of formal ethics, if and only if $\Omega=+=\mathrm{b}$, i. e. iff $\Omega$ is the negative constant-moral-valuation-function. A visual model of logic interrelation between the concepts "formal-ethical-contradiction" and "formal-logical-contradiction" is presented in (Lobovikov, 2015c; 2016).

Definition 4 (of formal-ethical-consequence-relation): in two-valued algebra of formal ethics, a moral-evaluation-function $\Omega$ formally-ethically follows from a moral-evaluation-function $\Psi$, if and only if the moral-evaluation-function $C \Psi \Omega$ acquires the moral value $g$ (good) under any possible combination of moral values of its variables. In other words, $\Omega$ formally-ethically follows from $\Psi$, if and only if $C \Psi \Omega=+=g$. In the expression $C \Psi \Omega$, the symbol $C$ is used in that specific moral-value-functional-sense which is precisely defined above by the table 1 (column 3) as St.-Augustine's definition (of God's adequate moral-reaction to human deeds). The logic interrelation between "formal-ethical-consequence" and "formal-logical-consequence" is modeled graphically in (Lobovikov, 2015c; 2016).

According to the above-submitted model of St.-Augustine's doctrine, the fallen men have no possibility to determine Gods decisions concerning the options of their future eternal life: in relation to bad humans it is good that His decisions about them are arbitrary from their viewpoint. The above-presented table 1 convincingly demonstrates that, according to Augustine, only God's Grace (represented by the row 3 of the table 1) makes up grounds for the hope of wicked men.

\section{AUgustinianism, MORAL RIGOR-ISM AND ClassiCal LOGIC; HUMANISM, REALISM, AND NON-CLASSICAL LOGIC}

According to the table 1, the distinction between Augustine's and Pelagius' doctrines exists only in the row 3 of the table: in all the rest rows there is no difference between the two thinkers. The submitted tabular model of the debate between Augustine and Pelagius is heuristically and pedagogically valuable as it helps easily to understand why Pelagius was irritated by Augustine's definition of the moral operation $C x y$ (represented by the table 1). Pelagius was irritated by the row 3 of the tabular definition. Logically thinking he figured out that if the rows 3 and 4 of the column 3 of the table 1 are accepted, then God's absolutely arbitrary rule (voluntarism) in relation to bad men is good: consequently, in relation to the men God's good reaction to the men deeds is absolutely contingent one; no men can perfectly know God's Last Judgment concerning them. Using the system of moral values of humanism, empiricism, relativism, representatives of Pelagius's heresy struggled against Augustinianism on principle. To elaborate a logically well-equipped critical attitude to the heresy in question here it is very important to understand clearly which principle is implied by Pelagius and his adherents when they rebel against Augustinianism. 
Any model must be similar to its original. Hence constructing the model of the indicated aspect of Augustine's legacy must be implemented in accordance with Augustine's original religious position and writings. In accordance to his writings, any terrestrial (material) man is evil (even newborn babies are not innocent); it is impossible for such a man to obtain Salvation without God's Grace. Only His Grace (represented in the model by the row 3 of the column 3 of the table 1) is a basis for the man's hope. Why? At the level of the submitted two-valued algebraic model of formal ethics it is possible to answer this question in the following way. In two-valued algebraic system of formal ethics under exploitation in this article, the algebraic (formal-axiological) equation $C b y=+=g$ is true for every (arbitrarily taken) $y$. Here it is relevant to remind that (in the artificial language used in this paper) the letters " $b$ " and " $g$ " stand for "bad" and "good", respectively. The expression Cby is a result of substituting the moral-value $b$ ("bad") for the variable $x$ in the expression $C x y$, which stands for the moral operation "realizing $y$ in response to realizing $x$ ". In the above formal-axiological equation $C b y=+=g$, it is implied that $C x y$ is interpreted and defined (by the above table 1) according to Augustine, i. e., by definition, $C x y=+=C A x y$

Obviously, the humanists (defined as those who love material humans and try to defend them as such, i. e. as not spiritual but material, fleshy ones) could not be happy with respect to the submitted mathematical model; they should not accept it; they ought to evaluate it as not realistic, inhuman and not adequate. However here it is very important to clarify the label "not realistic, not adequate". What or who is labeled in this way? The first option - "not realistic, not adequate" is ascribed to the submitted mathematical model of the original which original is the specific aspect of Augustinianism under discussion in this chapter. I believe that this option is to be rejected resolutely as the above-submitted model is adequate to its original: it precisely simulates the original conception of Augustine. In this relation the above-submitted algebraic system of formal ethics of rigor morality is quite a realistic model of the original - Augustine's moral rigor doctrine. The second option - the label "not realistic, not adequate" is ascribed to the original - Augustine's religious philosophy of moral rigor. The typical fleshy (material) humans and the empiricist-minded humanists do not like the moral rigor on principle. Therefore, they do not like the religious ethics of pure Augustinianism and radical Protestantism (Beachy 1977; Schwiebert, 1950) because the two respectable religious systems represent the moral rigor on principle.

From the viewpoint of the present article the religious doctrine of moral rigor-ism is grounded upon the below-defined functionally complete set $\{N, K, C\}$ of moral-operations of the classical (two-valued) algebra of formal ethics. The moral-evaluation-functional-sense of unary-moral-operation $N x$ - "nonbeing of $x$ " is precisely defined by the following table 3 . The same table defines the moral-value-functional-sense of the unary-moral-operations: $B x$ - "being of $x$ "; $R x$ - "resistance to $x$ "; $H x$ - "help, assistance to $x$ ". $T x$ - "termination, annihilation of $x$ ". The algebraic operations $B, R, H, T$, belonging to the set $F$ (from the above-mentioned triple $<A, F,=+=>$ ), are not utilized in the paper. They are placed in the table 3 for exemplification of the general notion "unary-moral-operation of two-valued algebra of formal ethics".

TABLE 3

\begin{tabular}{|cccccc|}
\multicolumn{7}{c}{ Unary operations } \\
\hline$x$ & $N x$ & $B x$ & $R x$ & $H x$ & $T x$ \\
\hline $\mathrm{g}$ & $\mathrm{b}$ & $\mathrm{g}$ & $\mathrm{b}$ & $\mathrm{g}$ & $\mathrm{b}$ \\
$\mathrm{b}$ & $\mathrm{g}$ & $\mathrm{b}$ & $\mathrm{g}$ & $\mathrm{b}$ & $\mathrm{g}$ \\
\hline \multicolumn{7}{c}{ Source: Own elaboration }
\end{tabular}

The glossary for the below-presented table 4: The symbol Kxy stands for the moral-evaluation-function "uniting, conjoining, combining moral actions $x$ and $y$ in a conduct as a whole". Cxy stands for the moral-evaluation-function "performing action $y$ in response to action $x$ ". (The binary algebraic operations $K$ and $C$ belong to the set $F$ from the above-mentioned triple $<A, F,=+=>$.) The moral-evaluation-functional-sense of the mentioned operations of algebra of formal ethics of moral rigor is defined by the following table 4 . 
TABLE 4

Binary operations

\begin{tabular}{cccc}
\hline $\mathrm{x}$ & $\mathrm{y}$ & $K x y$ & $C x y$ \\
\hline $\mathrm{g}$ & $\mathrm{g}$ & $\mathrm{g}$ & $\mathrm{g}$ \\
$\mathrm{g}$ & $\mathrm{b}$ & $\mathrm{b}$ & $\mathrm{b}$ \\
$\mathrm{b}$ & $\mathrm{g}$ & $\mathrm{b}$ & $\mathrm{g}$ \\
$\mathrm{b}$ & $\mathrm{b}$ & $\mathrm{b}$ & $\mathrm{g}$ \\
\hline
\end{tabular}

Source: Own elaboration

It is natural to expect that the above-presented table 4 shall be criticized by the humanists of all kinds. First of all, it shall be criticized for being too rigorous, too unrealistic, and too inhuman. However, notwithstanding this psychologically natural expectation, the above table 4 is an adequate discrete mathematical model of the original - Augustine's religious-moral-rigor-doctrine worthy of being called "classical" one of formal ethics as a consistent system of absolutely-universal-and-immutable-positive-moral-values of activity.

Being translated from the artificial language of the model to the natural one, the equation $C b y=+=g$ means that God's absolutely arbitrary action in response to terrestrial men's activity is absolutely good: this good response-action of God is a (universal and immutable) law of the two-valued algebra of morals. (The precise definition of the notion "law of the two-valued algebra of morals" is given above: see the definition 2.) To examine this very important and nontrivial theological thesis it is necessary and enough: (1) to "compute" accurately the moral-evaluation-function Cby; and (2) to apply (take into an account) the above-given precise definitions 1 and 2.

In relation to the above-said the humanists Pelagius (Pohle, 1911), Erasmus of Rotterdam (Dolan, 1964), Marsilio Ficino (Celenza, 2017), Pico della Mirandola (Dougherty, 2008), and others (Cassirer et al., 1948; Kristeller, 1964) used to object that: a terrestrial (fleshy) man (as a whole) is not a pure evil; as a whole the real terrestrial man (and his activity as a whole) is uniting (combining) good and bad in a complicated mixed system. Hence, in principle, it is possible: effectively to separate good and bad in the terrestrial man; effectively to isolate, restrict, and neutralize evil in humans (and in their activities) as complex systems. If such separating, isolating, limiting, and neutralizing evil in humans (and in their activities) is realized then the humans have a possibility to produce their salvation by their own efforts exclusively. Consequently, God's Grace is an excessive one: the men are free and using their freedom adequately they can determine God's positive Last Decision concerning them (and they can be perfectly sure that they do know His Last Decision about them). The rows 1 and 2 of the table 1 make up a theoretical basis of/for the men's confidence in possibility of their salvation by means of their own efforts (good deeds) exclusively (without God's help). If absolutely all actions of a terrestrial person are good, then God is morally determined to evaluate the person positively (according to the person's absolutely good activity) and, finally, to save him.

However, the above-indicated impressive external argumentation of humanists versus Augustinianism is not an argumentation versus adequateness of the suggested discrete mathematical model of the aspect of Augustinianism under review. The presented model is adequate to its original - authentic Augustine's viewpoint. From the internal viewpoint of Augustinianism, the humanistic counter-argumentation is defective. Why? It is defective from the internal viewpoint of Augustine because his ethics is a religious philosophy of absolute moral rigor. According to the philosophy of absolute moral rigor-ism, adequately modeled by the above presented two-valued algebra of formal ethics (of moral rigor-ism), it is true that $\mathrm{Kg} b=+=b$ : uniting (combining) good and bad actions in a complicated (mixed) system of human conduct (as a whole) is bad. (See the definition of the binary-moral-operation Kxy given above by the table 4.) Hence, $C K g b y=+=g$. As the unity ( $\mathrm{Kgb})$ of good and bad (actions) is bad, God's realizing an arbitrary action $y$ in response to human's $K g b$ is absolutely good, i. e. a formal-ethical-law of two-valued algebra of rigorous morality. 
The above-submitted table 4 can be criticized from different points of view. But it is indispensable to make difference between (1) critique of moral rigor-ism as not adequate attitude to real humans, and (2) critique of model of moral rigor-ism as not adequate to its original. In my opinion, the main idea of possible options of criticizing the table 4 is attack on the moral rigor-ism as not adequate attitude to real humans. Terrestrial humans would like to have morals and laws which are more human-friendly, more realistic and hence less rigorous to not-absolutely-perfect human activity and personality. This desire and tendency of the terrestrial men is quite understandable and predictable. But then it is quite natural a priori to figure out (by the analogy) that the same desire and tendency exists among logicians: they criticize the two-valued classical logic for its excessive rigor making the logic not-realistic, not-human one (Costa, 1974; Costa et al., 2007; Béziau, 1999; Béziau \& Costa 2015).

If the above-considered thesis of Łukasiewicz is true, i. e. iflogic is morals of thought and speech, then there should be a strong tendency of/for deviating significantly from the rigorous-(classical-logic)-ideal of thinking and speaking.

Actually, such a strong desire and tendency does exist in contemporary symbolic logic: A great amount of significantly different non-classical logic systems is invented, elaborated and investigated today. In relation to the present article's theme, the most interesting branches of the contemporary non-classical symbolic logic are relevant logics (Anderson \& Belnap 1975; Mares, 2004) and paraconsistent ones (Costa, 1974; Costa et al., 2007; Béziau, 1999; Béziau \& Costa, 2015; Priest et al., 1989). Thus, the moral humanism-and-empiricism (which is a moral analogue of the great variety of non-classical, especially relevant and paraconsistent, logic systems) makes up an alternative for moral-rigor-ism. Nevertheless, despite the progress in making plenty of non-classical logics, the classical two-valued logic is not completely rejected, neglected and forgotten. On the contrary, it is a necessary foundation for all the non-classical experiments.

Therefore, I think (by analogy) that, being the analogue of classical logic, Augustine's religious philosophy of the natural-law-and-morals shall be significant forever. It shall be important for all times and places, for all possible cultures and people, because it is a necessary foundation for all the non-classical experiments with moral rigor norms of activity in general. Hence, I think that the above-submitted discrete mathematical model of Augustine's moral doctrine is worth taking seriously and studying systematically.

At the end of the paper I would like to mention that heuristic and pedagogical potential of the discrete mathematical model under consideration is not reduced to effective analyzing Augustine-Pelagius controversy only. The submitted mathematical model gives a possibility to compare not only Pelagius' heresy but also Leo Tolstoy's one with the classical doctrine of Augustine of Hippo. The count manifestly expressed his religious views in many publications, especially in (Tolstoy, 1942; 1970; 1990; 2005; 2009). It is the fact that Russian Orthodox Church assessed his religious doctrine as a heresy and rejected to change this assessment several times. The Church insists that the negative assessment of the count's moral-theology doctrine is produced not in result of mistake but on principle. Which principle is implied? According to the discrete mathematical model considered in this article the implied principle is represented by the row 3 of the above-given table 1 . This row demonstrates visually the important difference between the classical doctrine of Augustine and the heretic one of Tolstoy. Moreover, this row shows clearly the significant difference between the two heresies under consideration in the present paper. If the rows 1 and 2 of the table 1 are not taken into an account (only the rows 3 and 4 are considered) then the heretic religious doctrines of Pelagius and Tolstoy are directly opposite (contradictory) ones. This result of the above tabular modeling moral-theology views of Tolstoy and Pelagius (and comparing them at the tabular-model level) is worth taking into an account by those theologians who investigate heresies systematically.

\section{Conclusion}

The article has claimed that philosophical theology and formal ethics are foundational for logic. Developing and exemplifying this claim has resulted in constructing a discrete mathematical model of Augustine's "On Grace 
and Free Choice", and in comparing Augustine's conception (of morally good acting-in-response) with corresponding views of Tolstoy and Pelagius at the model level. For the first time in philosophical-theology literature by comparing corresponding moral-value-tables it is demonstrated that there is a surprising analogy between the material implication in classical logic and the binary-moral-operation "realizing action $y$ in response to action $x$ " in two-valued algebraic system of formal ethics (of moral rigor) modeling relevant Augustine's conception. The article has represented hitherto never undertaken attempt of constructing and investigating a visual tabular-model of the specific synthesis of Law and Grace in Augustinianism. By means of the discrete mathematical model it is shown that Augustinianism is quite a logical doctrine of formal ethics of moral rigor. By the analogy under consideration in the article, not only Augustine's rigorous (even severe) moral theology is associated with the classical (two-valued) algebraic system of formal logic, but also the humanism-and-realism is associated with the infinite variety of possible deviations from the classical symbolic logic which variety makes up a real problem for today philosophy of logic.

The algebraic system of formal ethics (as formal axiology) precisely defined and systematically exploited above in this paper is helpful not only for discrete mathematical modeling the conceptions of morally adequate acting in response. The two-valued algebraic system of formal axiology is effective also for discrete mathematical modeling the famous tenets of God's omnipresence (Lobovikov, 2017) and God's omnipotence (Lobovikov, 2019). I believe that many other famous tenets of philosophical theology could be successfully modeled by means of the algebraic system of formal ethics as formal axiology. However, examining this belief is a subject-matter for future investigations.

\section{Agradecimientos}

Se agradecen los comentarios de los árbitros de la revista que mejoraron sustancialmente el contenido del artículo.

\section{REFERENCES}

Anderson, A. R., \& Belnap, N. D. (1975). Entailment: The Logic of Relevance and Necessity. Vol. I. Princeton, N. J.: The University Press.

Aquinas, T. (1975). Summa contra Gentiles. Notre Dame: University of Notre Dame Press.

Aquinas, T. (1994a). The Summa Theologica. V. I. In Adler Mortimer (Ed.), Great Books of the Western World. V. 17. Aquinas: I. Chicago, Auckland, London, Madrid: Encyclopedia Britannica, Inc.

Aquinas, T. (1994b). The Summa Theologica. V. II. In Adler Mortimer (Ed.), Great Books of the Western World. V. 18. Aquinas: II. Chicago, Auckland, London, Madrid: Encyclopedia Britannica, Inc.

Augustine, A. (1963). The Trinity. Washington, D. C.: The Catholic University of America Press.

Augustine, A. (1994). The Confessions. The City of God, On Christian Doctrine. In Adler Mortimer (Ed.), Great Books of the Western World. V. 16: Augustine. Chicago, Auckland, London, Madrid: Encyclopedia Britannica, Inc.

Augustine, A. (2010). On Grace and Free Choice. In Augustine. On the Free Choice of the Will, On Grace and Free Choice, and Other Writings (pp. 141-184). Cambridge: The Univ. Press.

Beachy, F. J. (1977). The concept of Grace in the Radical Reformation. Nieuwkoop: De Graaf.

Béziau, J.-Y. (1999). What is paraconsistent logic? In Frontiers of paraconsistent logic (pp. 95-112). Baldock: Research Studies Press. 
Béziau, J.-Y. (2015). The logical hexagon of analogy: Structuring the relations between difference, identity and similarity. In Katarzyna Gan-Krzywoszyńska, Małgorzata Leśniewska, Przemysław Krzywoszyński, Piotr Leśniewski (Eds.), Handbook of the First World Congress on Analogy, Benemérita Universidad Autónoma de Puebla, Puebla, Mexico, November 4-6, 2015 (pp. 12-13). Poznań: Publishing House KONTEKST.

Béziau, J.-Y., \& Costa, N. da. (2015). Is God paraconsistent? In Ricardo Sousa Silvestre and Jean-Yves Beziau (Eds.), Handbook of the 1st World Congress on Logic and Religion, João Pessoa, April 1-5, Brazil (p. 25). Federal University of Campina Grande, Federal University of Paraiba, Federal University of Rio de Janeiro, Brazilian Academy of Philosophy: João Pessoa:

Bobzien, S. (2015). Ancient Logic. In Edward N. Zalta (Ed.), The Stanford Encyclopedia of Philosophy (Winter 2016 Edition). Retrieved from https://plato.stanford.edu/archives/win2016/entries/logic-ancient/.

Bonner, G. (1963). St. Augustine of Hippo. Philadelphia: Westminster Press.

Bonner, G. (1987). God's decree and man's destiny: Studies on the thought of Augustine of Hippo. L.: Variorum Reprints.

Cassirer, E., Kristeller, P. O., \& Randall, J. H. Jr. (1948). The Renaissance Philosophy of Man. Chicago: The University of Chicago Press.

Celenza, C. S. (2017). Marsilio Ficino. In Edward N. Zalta (Ed.), The Stanford Encyclopedia of Philosophy. Retrieved from http://plato.stanford.edu/archives/fall2017/entries/ficino/.

Costa, N. C. A. da (1974). On the theory of inconsistent formal systems. Notre Dame Journal of Formal Logic, 15, 497-510.

Costa, N. C. A. da, Krause, D., \& Bueno, O. (2007). Paraconsistent logics and paraconsistency. In D. Jacquette (Ed.), Philosophy of Logic: Handbook of the Philosophy of Science (pp. 791-912). North-Holland.

Couenhoven, J. (2007). Augustine's rejection of the free-will defense: An overview of the late Augustine's theodicy. Religious Studies, 43(3), 279-298.

Dolan, J. P. (Ed.) (1964). The essential Erasmus. N. Y.: Mentor Books/New American Library.

Dougherty, M. V. (Ed.). (2008). Pico della Mirandola. New Essays. Cambridge: The University Press.

Epstein, R. L. (2001). Propositional logics: The semantic foundations of logic (2nd edition). Belmont, C. A.: Wadsworth/Thomson Learning.

Farrelly, D. M. J. (1964). Predestination, Grace, and Free Will. Westminster, Maryland: The Newman Press.

Fitzgerald, A. D. (Ed.) (1999). Augustine through the ages. Grand Rapids, M. I.: Erdmans Publ. Co.

Hume, D. (1977). A treatise of human nature. London: Dent; New York: Dutton.

Husserl, E. (1988). Vorlesungen über Ethik und Wertlehre, 1908-1914 [Lectures on Ethics and Value Theory, 1908-1914]. Husserliana, 28. Dordrecht: Kluwer.

Kleene, S. C. (1967). Mathematical logic. New York: Wiley.

Kristeller, P. O. (1964). Eight philosophers of the Italian Renaissance. Stanford, C. A.: Stanford Iniversity Press.

Lancel, S. (2002). Saint Augustine. L.: SCM Press.

Leibniz, G. W. (1971). Elementa Juris Naturalis. In G. W. Leibniz. Philosophishe Schriften. Erster Band (16631672). Berlin: Akademie-Verlag.

Lobovikov, V. (1984). Modal Logic of Evaluations and of Norms from the Viewpoint of Contents of Ethics and Law. Krasnoyarsk: University of Krasnoyarsk Press.

Lobovikov, V. (1988). Artificial Intelligence, FormalEthics, and Moral-Legal Choice. Sverdlovsk: Ural State University Press.

Lobovikov, V. (1990). Formalization of Activity (Values and Norms). The Hab. Doctor Dissertation. Sverdlovsk: Ural State University. 
Lobovikov, V. (1998). Mathematical Jurisprudence. Part 1: The Natural Law. Yekaterinburg: The Ural State Law Academy Press; Liberal Arts University Press.

Lobovikov, V. (1999). Mathematical Jurisprudence and Mathematical Ethics (A mathematical simulation of the evaluative and the normative attitudes to the rigoristic sub-systems of the Positive Law and of the Natural-Law-and-Morals). Yekaterinburg: The Ural State Law Academy Press; Liberal Arts University Press.

Lobovikov, V. (2007). Mathematical Ethics, Metaphysics and the Natural Law (Algebra of Metaphysics as Algebra of Formal Axiology). Yekaterinburg: Institute of Philosophy and Law of Ural Branch of Russian Academy of Sciences.

Lobovikov, V. (2009a). Mathematical Logic as a Particular Case of Mathematical Ethics (Algebra of Formal Ethics as a Generalization of Algebra of Formal Logic). In Costas Drossos; Pavlos Peppas; Constantine Tsinakis (Eds.) Proceedings of the 7th Panhellenic Logic Symposium (PLS7) at Patras University, Greece, July 15-19, 2009 (pp. 109-111). Patras, Greece: Patras University Press.

Lobovikov, V. (2009b). Mathematical simulating formal axiological semantics of natural languages (A fundamental generalization of mathematical philosophy: from truth-values to axiological ones). In Philosophy, mathematics, linguistics: aspects of interconnection: Proceedings of the International scientific conference, November 20-22, 2009, Sankt-Petersburg, L. Euler International mathematical institute (pp. 128-132). St.-Petersburg: VVM.

Lobovikov, V. (2014a). Algebra of Morality and Formal Ethics. In Katarzyna Bronk (Ed.) Looking Back to See the Future: Reflections on Sins and Virtues (pp. 17-41). Oxford, United Kingdom: Inter-Disciplinary Press.

Lobovikov, V. (2014b). Augustine-the-Blessed's doctrine of God's reward from the viewpoint of two-valued algebra of formal ethics. Yearbook of the Institute of Philosophy and Law of the Ural Branch of the Academy of Sciences, 2, 52-66.

Lobovikov, V. (2015a). Discrete Mathematical Representations of the Heresies of Pelagius and Leo Tolstoy, and of their Interrelations with St. Augustine's Doctrine of Grace and Free Choice. In Abstracts of the International Conference "Formal Methods and Science in Philosophy", March 26-28, 2015, Croatia (pp. 16-17). Dubrovnik: Inter-University Centre.

Lobovikov, V. (2015b). The Trinity Triangle and the Homonymy of the Word "Is" in Natural Language: Eliminating the Illusion of Logical Inconsistency by Precise Formulating the Principle of Separation of Facts and Values in Algebra of Formal Ethics. In Ricardo Sousa Silvestre and Jean-Yves Beziau (Eds.), Handbook of the 1st World Congress on Logic and Religion, João Pessoa, April 1-5, 2015, Brazil (pp. 176-177). João Pessoa: Federal University of Campina Grande; Federal University of Paraiba; Federal University of Rio de Janeiro; Brazilian Academy of Philosophy.

Lobovikov, V. (2015c). The Trinity Triangle and the Homonymy of the Word "Is" in Natural Language (A Logically Consistent Discrete Mathematical Representation of the Trinity by Means of Algebra of Morality and Formal Ethics).Philosophy Study, 5(7), 327-341 (2015). https://doi.org/10.17265/2159-5313/2015.07.001.

Lobovikov, V. (2015d). Two Worlds, Two Languages, Two Semantics, Two Linguistic Principles of Compositionality, and Two Kinds of Nonsenses (Criticizing Wittgenstein's philosophy of morals and of metaphysics by means of discrete mathematical modeling a formal-ethical aspect of his worldview). Journal of Siberian Federal University. Series: Humanities \& Social Sciences, 8(5), 901-911.

Lobovikov, V. (2015e). The Principle of Compositionality in Formal-Axiological Semantics of Natural Language. Journal of Ural Federal University. Series 3: Social Sciences, 140(2), 84-97.

Lobovikov, V. (2016). An Equivalence of Moore's Paradox and Gödel's Incompleteness Sentence in Two-Valued Algebra of Formal Ethics. Philosophy Study, 6(1), 34-55. https://doi.org/10. 17265/2159-5313/2016.01.004.

Lobovikov, V. (2017). Proving God's Omnipresence by Calculating Compositions of Evaluation-Functions in Two-Valued Algebra of Metaphysics as Formal Axiology. In Book of Abstracts of the 2 nd World Congress on 
Logic and Religion, Warsaw, June 18-22, 2017 (p. 56). Warsaw: Institute of Philosophy of the University of Warsaw.

Lobovikov, V. (2019). Analytical Theology: God's Omnipotence as a Formal-Axiological Law of the Two-Valued Algebra of Formal Ethics (Demonstrating the Law by "Computing” Relevant Evaluation-Functions). Tomsk State University Journal of Philosophy, Sociology, and Political Science, 47(1), 87-93. https://doi. org/10.17223/1998863X/47/9.

Mates, B. (1961). Stoic Logic. The University of California Press.

Mares, E. D. (2004). Relevant logic: A philosophical interpretation. Cambridge: The University Press.

Mendelson, E. (1997). Introduction to mathematical logic. London; New York: Chapman \& Hall.

Moore, G. E. (2004). Principia Ethica. Mineola, N. Y.: Dover Publications.

Pohle, J. (1911). Pelagius and Pelagianism. In Catholic Encyclopedia. Vol. 11. N. Y.: Robert Appleton Company.

Priest, G., Routly, R., \& Norman, J. (Eds.). (1989). Paraconsistent logic: Essays on the inconsistent. München: Philosophia Verlag.

Pseudo-Dionysius. (1980). The Divine Names and Mystical Theology. Milwaukee, W. I.: Marquette University Press.

Rist, J. M. (1994). Augustine: Ancient thought baptized. N. Y.: Cambridge University Press.

Schwiebert, E. G. (1950). Luther and his times. St. Louis: Concordia Publishing House.

Tillich, P. (1968). A history of Christian Thought. N. Y.: Harper \& Row.

Tolstoy, L. (1942). What then must we Do? London: Oxford University Press.

Tolstoy, L. (1970). The law of love and the law of violence. London: Anthony Blond.

Tolstoy, L. (1990). Government is violence: Essays on anarchism and pacifism. London: Phoenix Press.

Tolstoy, L. (2005). The Kingdom of God is within you: Christianity not as a mystical religion but as a new theory of life. N. Y.: Barnes \& Noble Books.

Tolstoy, L. (2009). My Religion-What I Believe. Guildford: White Crow Books.

Watson, P. S. (1959). The concept of Grace. Philadelphia: Muhlenburg Press.

Wetzel, J. (1992). Augustine and the Limits of Virtue. N. Y.: Cambridge University Press.

Woleński, J. (2019). Lvov-Warsaw School. In Edward N. Zalta (Ed.), Stanford Encyclopedia of Philosophy (Spring 2019 Edition). Retrevied from http://plato.stanford.edu/archives/spr2019/entries/lvov-warsaw/.

Yates, J. P. (2006). Selected remarks on some of Augustine's unique exegesis of the catholic epistles in the pelagian controversies. In F. Young (Ed.), Studia Patristica Vol. XXX. Papers presented at the Fourteenth International Conference on Patristic Studies held in Oxford 2003 (pp. 303-321). Leuven: Peeters.

\section{Notas}

[1] The symbols "g" and "b" (used systematically hear-after) stand for "good" and "bad" respectively. The words "good" and "bad" are used in their proper moral meanings.

[2] From the empirical point of view sometimes it is hard to see how propositions can be moral actions. Nev-ertheless, from the theoretical viewpoint it can be reasonable to make a convention to accept the abstraction or idealization, according to which true propositions are to be treated as good actions and false propositions are to be treated as bad ones. I think that accepting the mentioned idealization (generalization) can be fruitful for progressive developing the theoretic discourse.

\section{BY-NC-ND}

